\title{
Prediction of Potential Electrical Energy Generation from MSW of Basrah Government
}

\author{
Abdul Hussain A. Abbas, Wesam S. N. Al-Rekabi, Ahmed N. A. Hamdan \\ Civil Engineering Department, College of Engineering., University of Basrah, Basrah-Iraq
}

\begin{abstract}
The energy crisis and environmental degradation are currently two vital issues for global sustainable development. The main objective of the present study is to evaluate the characteristics and energy potential of municipal solid waste (MSW) for electrical power generation in Basrah Governorate in the south of Iraq. A minimum records of per capita solid waste generation was $1.05 \mathrm{~kg}$ per person per day for years (2011-2014) an average density of $206.7 \mathrm{~kg} / \mathrm{m}^{3}$ and moisture content of 42.3\%. Waste composition is composed mainly of food waste at $60.5 \%$, followed by Plastic at $14.5 \%$, paper at $7.2 \%$, Wood at $5.0 \%$, textiles at $4.1 \%$, glass at $2.8 \%$, metal at $2.7 \%$ and rubber at $0.6 \%$. Waste generated could be used as an intermediate in different processes such as $60.5 \%$ composting of organic and $37 \%$ recycling materials. The chemical formula of a MSW of Basrah city was found to be $C_{620} H_{953} O_{312} N_{16} S$ with sulfur and without sulfur as $C_{38} H_{58} O_{19} N$. Dulong's Equation was used to determine the heating values with the data obtained from the ultimate analysis. The waste to energy (WTE) plant will export to the grid not less than $158 \mathrm{MW}$ of electricity of waste incinerated. this electricity generation would provide roughly $21 \%$ of the energy needed for Basrah Governorate. Furthermore, this electricity generation will translate into approximately US\$ 69 million revenues per year from the WTE plant. The WTE will be profitable until discount rate 12\%. The maximum capacity for power generation is projected to be around $270 \mathrm{MW}$ in 2036. Finally, To meet up the power supply for city and reducing space for new landfills, WTE is playing a vital role for renewable energy production from discarded MSW.
\end{abstract}

Keywords: Solid waste, waste to energy, Dulong's formula, Incinerator, , Heating / Calorific values, Basrah, Iraq

\section{1- Introduction}

Municipal solid waste (MSW) comprises of combined domestic, commercial and industrial waste generated in a given municipality or locality. The quantity and rate of MSW generation in each state is a function of the population, level of industrialization, urbanization rates, local climate, social-economic status of the citizens and the kind of commercial activities predominant in the area. [1,2].

Solid waste management is the handling of discarded materials. One form of waste management involves the elimination of undesirable waste products by methods such as landfilling and incineration. In most cases, wastes are disposed of only by landfilling where the waste is exposed to air. This results in obvious visual pollution and odor pollution of surrounding areas. It is established that the landfill sites are sources of gas production resulting from chemical reactions and microbes acting upon the waste as the biodegradable materials begins to break down [3].

Traditionally solid waste would have been disposed in a landfill site or incinerated in mass burning facilities without heat or energy recovery. The incinerators of the past were progressively transformed to the modern waste-to-energy (WTE) power plants that are fuelled by solid waste. Waste-to-energy (WTE) is an established option for municipal solid waste (MSW) treatment, motivated by both the necessity to, minimise the environmental stresses of landfilling due to reduce the volume of the original waste by $90 \%$ and the aim to increase the share of renewable energy in the form of electricity or heat that can be conveniently used for power generation $[4,5]$.

The processes for conversion of waste to energy (WTE) recover the energy from waste through direct combustion (e.g., incineration, pyrolysis, and gasification) or produce combustible fuels such as hydrogen, methane, and other synthetic fuels (e.g., anerobic digestion, biological treatment, and refuse-derived fuel) 
(ASME). The processes for conversion of waste to energy can shorten the landfill site by reducing the volume of the waste and can also reduce the need for fossil fuels and emission of greenhouse gases (GHG). According to American Environmental Protection Agency's (EPA) report, waste energy is considered a renewable source of energy [6].

In several developed countries, incineration has become one of the two most used waste disposal method. Waste incineration thus appears as an interesting alternative to the traditional disposal methods and can no longer be overlooked in several circumstances [7].

The exploitation of the non-conventional energy locked up in the urban solid municipal waste into grid energy through WTE will provide the dual advantage of minimising waste and recovering the 'hidden' energy. This makes it a very attractive waste management/power generation option for Iraq due to this country has had a serious crisis of electricity.

Municipal solid waste is a major environmental hazard and social problem in Basrah Governorate in southern Iraq. Another major problem facing the society is a serious crisis of electricity. The literature available presents some idea of what quantity of waste is generated, its composition and characteristics, but its suitability for power generation has not yet been fully addressed and needs to be if a certain waste is being considered for power generation. The main objective of the study was to evaluate the electrical energy potential that generated from MSW of Basrah Governorate.

\section{2- Waste to Energy (WTE) Plant}

The use of WTE as a waste management option also has positive externalities. WTE reduces the space required by landfill by about 90 percent with an added benefit of avoiding the aqueous emissions from landfills and electricity can be generated at the same time. Recovery of ferrous and non-ferrous metals is also possible from WTE. The combustion of each ton of MSW can generate as much electricity as 0.28 tons of coal or 25 gallons of oil [8]. The modern WTE plants of adopt three process are combustion, Boiler/ steam turbine, and exhaust gas cleaning as illustrated in Fig. 1. In the combustion process, heat generated from the oxidation of the waste feedstock boils water into steam for driving the steam turbines that generate electricity. Excess flue gases pass through multiple stages of filtering before exiting the system. To increase efficiency, the heat from steam can be collected and reused for heating and generating power, through Combined Heat and Power (CHP) or cogeneration. Average energy efficiency of the incineration plants is 39\% [9].

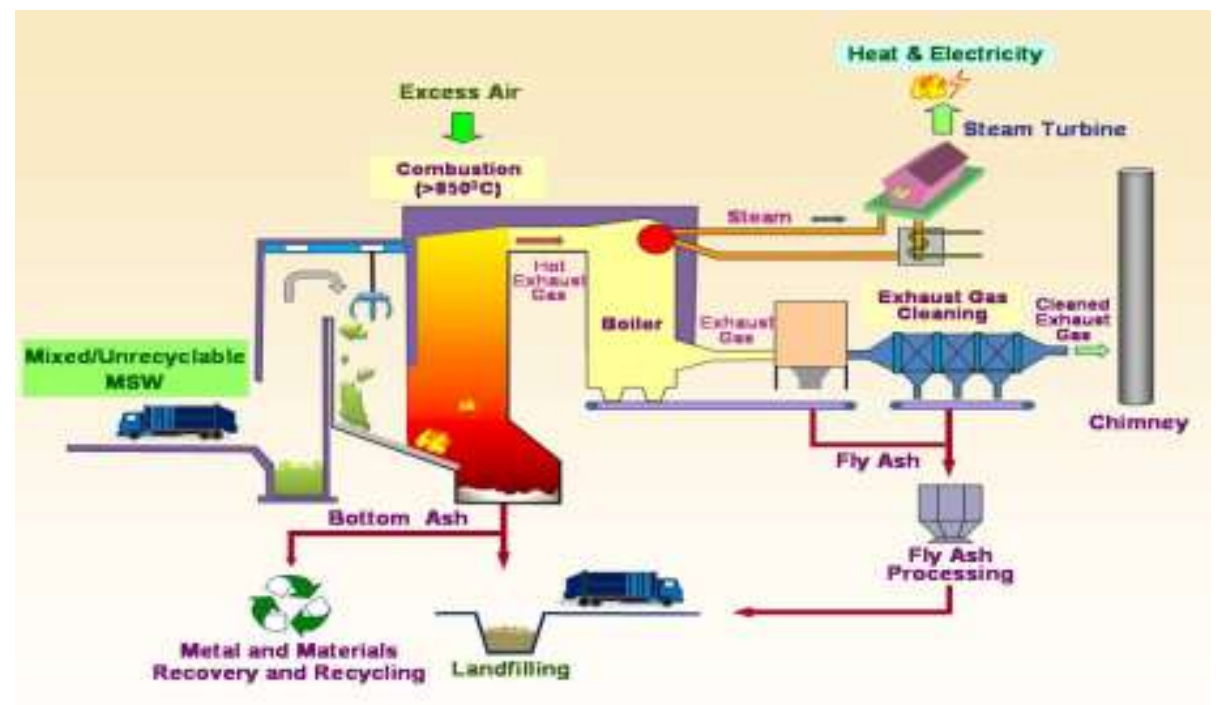

Fig. 1: The typical processes in an WTE plant 


\section{3- Study Area}

The study was conducted at Basrah Governorate, Iraq. The Governorate lies on latitude $6^{\circ} 16^{\prime} 0.47 " \mathrm{~N}$ and longitude $0^{\circ} 2^{\prime} 40.75^{\prime \prime E}$ (Google Map Data, 2013). Basrah is the second Governorate in Iraq regarding volume of population and considered as the commercial capital of Iraq, its only port overlooking the Arab Gulf and its main sea outlet. Basrah governorate has a hot and arid climate. humidity are however relatively high due to the vicinity of the Arab Gulf. The area of Basrah Governorate amounts to (19.070) sq km. Basrah governorate is subdivided into seven districts: Basrah, Abu Al-Khaseeb, AlMidaina, Al-Qurna, Al-Zubair, Fao, and Shatt Al-Arab as shown in Fig. 2.

In Basrah Governorate, there are three transfer stations, located in the center, north, and south zone (Table 1). The general configuration of these transfer stations is an open land/area where collection vehicles unload their waste.

TABLE I: Basrah Governorate MSW Zones [10]

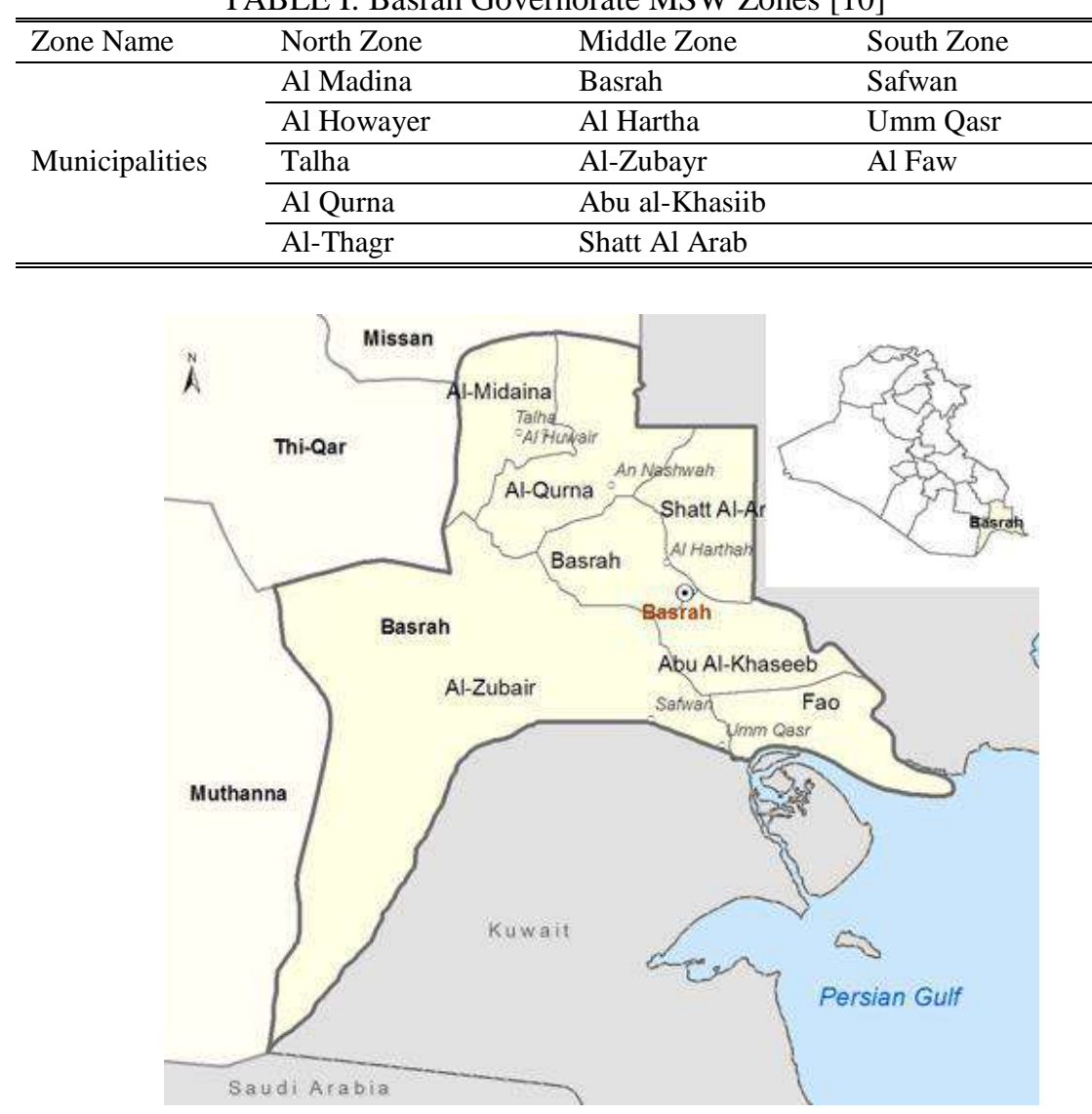

Fig. 2: Basrah Governorate Profile

\section{4- Physical Composition of MSW}

Random sampling was used to collect samples directly from the three transfer stations (center, north, and south zone) of Basrah Governorate for the characterisation of solid waste. Determination of waste material composition was done by way of physical segregation (manual sorting) and observation of collected wastes components. Each bag of waste was weighed, and then its contents emptied, sorted and weighed again. The percentage (\%) composition was categorised into nine major categories as shown in Table 2. Food waste was the most common component in Basrah Governorate, which was approximately $60.5 \%$ of the total MSW. Other 
fractions were $14.5 \%$ of plastic, $7.2 \%$ of paper, $5 \%$ of wood, 4.1 of textile, $2.8 \%$ of glass, and $2.7 \%$ of metal. Rubber has a small amount only $0.6 \%$.

TABLE II: Composition of MSW of Basrah Governorate

\begin{tabular}{lllll}
\hline \hline Item & North Zone & Middle Zone & South Zone & Average \\
\hline Food & 60 & 62.6 & 59 & 60.5 \\
\hline Plastic & 16 & 15.6 & 12 & 14.5 \\
\hline Metal & 2.7 & 2.6 & 2.8 & 2.7 \\
\hline Glass & 2.6 & 3.4 & 2.5 & 2.8 \\
\hline Paper & 7.8 & 7.5 & 6.2 & 7.2 \\
\hline Rubber & 0.8 & 0.5 & 0.5 & 0.6 \\
\hline Textile & 4.1 & 2.6 & 5.5 & 4.1 \\
\hline Wood & 4 & 3.5 & 7.7 & 5.0 \\
\hline Others & 2 & 1.7 & 3.8 & 2.5 \\
\hline \hline
\end{tabular}

\section{5- Recyclables and Compostable in MSW}

The percentage of Basrah Governorate municipal solid waste stream consisting of materials which are considered to be recyclable or compostable is significant. Findings based on field data estimate recyclable or compostable material to be about $97.5 \%$. Compostable (organic or food waste) make up on average $60.5 \%$ of the total MSW stream, while recyclables (plastics, metal, glass, wood, textile) make up 37\% of the total MSW stream. This large percentage of recyclable/compostable material in the waste stream provides optimism that large scale recycling and composting will be feasible and significantly reduce the volume of solid waste transferred to landfill.

\section{6- MSW Density}

The density of solid waste as discarded is determined by collecting a samples from the three waste transfer stations in the study area. Each sample of waste was put into the weigh box to overflowing. Weigh the filled box and calculate the bulk density using the formula (Eq. 1) below.

where:

$$
\text { Bulk Density }=(W-W T) / V
$$

$W=$ the weight of the box full,

$W T=$ the weight of the box empty, and

$V=$ the volume of the box determined

The density of municipal solid waste reported from the surveyed area (Table 3) ranged from $194.5 \mathrm{~kg} / \mathrm{m}^{3}$ to $218.2 \mathrm{~kg} / \mathrm{m}^{3}$ with an average density of $206.7 \mathrm{~kg} / \mathrm{m}^{3}$.

TABLE III: Average Density and Moisture Content of Municipal Solid Waste in Basrah Governorate

\begin{tabular}{ccccc}
\hline \hline Item & North Zone & Middle Zone & South Zone & Average \\
\hline MSW Density $\left(\mathrm{kg} / \mathrm{m}^{3}\right)$ & 207.4 & 218.2 & 194.5 & 206.7 \\
\hline MSW Moisture Content $(\%)$ & 45.7 & 39.0 & 42.2 & 42.3 \\
\hline \hline
\end{tabular}

\section{7- MSW Moisture Content}

The research has determined moisture content of waste according to the standard procedures. Samples were collected at random from the three waste transfer stations in the study area. Components of Samples will be segregated for major components such as organic, paper, plastic, metal, wood, textile, and glass. Initial weight of each category was measure, after which the samples were placed in electric oven at 90 oC for 48 hours. Dried weights were then record and calculation of moisture content was done with the following formula (Eq. 2);

Moisture Content $(\mathrm{MC})=100(\mathrm{~W}-\mathrm{D}) / \mathrm{W}$

where: $\mathrm{W}=$ Wet weight of sample

$\mathrm{D}=$ Dried weight of sample 
The moisture of municipal solid waste reported from the surveyed area (Table 3) ranged from $39.0 \%$ to $45.7 \%$ with an average moisture of $42.3 \%$.

\section{8- MSW Average generation rate}

Based on Iraqi Environmental Statistics records for years 2011- 2014 that presented in Table 4, the average generation rates of municipal solid waste were ranged from 1.05 to $1.97 \mathrm{~kg} /$ capita/day with an average generation rate of $1.4 \mathrm{~kg} / \mathrm{capita} / \mathrm{day}$. The minimum rate of MSW generation $(1.05 \mathrm{~kg} / \mathrm{capita} . / \mathrm{day})$ has been considered as MSW average generation rate for the study area in the next calculation.

TABLE IV: Population and MSW Quantities for Basrah Governorate as recorded by CSO [11]

\begin{tabular}{llll}
\hline \hline Year & Total Population (person) & Quantities of MSW (kg/day). & Average Rate kg/capita./day \\
\hline 2011 & $1,833,166$ & $3,606,732$ & 1.97 \\
\hline 2012 & $2,432,674$ & $3,176,923$ & 1.31 \\
\hline 2013 & $2,006,254$ & $2,105,479$ & 1.05 \\
\hline 2014 & $2,064,809$ & $2,639,589$ & 1.28 \\
\hline \hline
\end{tabular}

\section{9- Chemical composition of MSW}

Understanding the chemical composition of solid waste allows to evaluate alternative processing and recovery options. For example, the feasibility of combustion depends on the chemical composition of solid waste. One of the most important analysis for chemical properties is Ultimate analysis (major element). Ultimate analysis includes determination of mass percentages as discarded content in Carbon (C), Hydrogen (H), Nitrogen $(\mathrm{N})$, Sulfur (S), Oxygen (O), and Ash (A). Table 5 shows the typical data on ultimate analysis of the combustible components in solid [12] that are used in this study. The results of ultimate analysis for MSW of Basrah Governorate are calculated and listed in Table 6.

TABLE V: Typical data on ultimate analysis of the component in MSW (dry basis)

\begin{tabular}{|c|c|c|c|c|c|c|}
\hline \multirow[b]{2}{*}{ Compositions } & \multicolumn{6}{|c|}{ Percent By Weight Dry Basis } \\
\hline & $\mathrm{C}$ & $\mathrm{H}$ & $\mathrm{O}$ & $\mathrm{N}$ & $\mathrm{S}$ & A \\
\hline Food wastes & 48 & 6.4 & 37.6 & 2.6 & 0.4 & 5 \\
\hline Paper & 43.5 & 6 & 44 & 0.3 & 0.2 & 6 \\
\hline Cardboard & 44 & 5.9 & 44.6 & 0.3 & 0.2 & 5 \\
\hline Plastic & 60 & 7.2 & 22.8 & - & - & 10 \\
\hline Textiles & 55 & 6.6 & 31.2 & 4.6 & 0.15 & 2.5 \\
\hline Rubber & 78 & 10 & - & 2 & - & 10 \\
\hline Leather & 60 & 8 & 11.6 & 10 & 0.4 & 10 \\
\hline Garden trimmings & 47.8 & 6 & 38 & 3.4 & 0.3 & 4.5 \\
\hline Wood & 49.5 & 6 & 42.7 & 0.2 & 0.1 & 1.5 \\
\hline Glass & 0.5 & 0.1 & 0.4 & $<0.1$ & - & 98.9 \\
\hline Metals & 4.5 & 0.6 & 4.3 & $<0.1$ & - & 90.5 \\
\hline Dirt, ashes, brick etc. & 26.3 & 3 & 2 & 0.5 & 0.2 & 68 \\
\hline
\end{tabular}

TABLE VI: Chemical Composition of the solid waste for Basrah Governorate

\begin{tabular}{|c|c|c|c|c|c|c|c|c|}
\hline Composition & Food wastes & Plastic & Leather \& Rubber & Textile & Paper & Wood & Total & Unit \\
\hline \multirow{2}{*}{$\mathrm{C}$} & 48 & 60 & 60 & 55 & 43.5 & 49.5 & & $\%$ \\
\hline & 9.84 & 8.52 & 0.36 & 2.04 & 2.96 & 1.98 & 25.69 & $\mathrm{~kg}$ \\
\hline \multirow{2}{*}{$\mathrm{H}$} & 6.4 & 7.2 & 8 & 6.6 & 6 & 6 & & $\%$ \\
\hline & 1.31 & 1.02 & 0.05 & 0.24 & 0.41 & 0.24 & 3.27 & $\mathrm{~kg}$ \\
\hline \multirow{2}{*}{$\mathrm{O}$} & 37.6 & 22.8 & 11.6 & 31.2 & 44 & 42.7 & & $\%$ \\
\hline & 7.71 & 3.24 & 0.07 & 1.15 & 2.99 & 1.71 & 16.87 & $\mathrm{~kg}$ \\
\hline \multirow{2}{*}{ S } & 0.4 & 0 & 0.4 & 0.15 & 0.2 & 0.1 & & $\%$ \\
\hline & 0.08 & 0 & 0 & 0.01 & 0.01 & 0 & 0.11 & $\mathrm{~kg}$ \\
\hline
\end{tabular}




\begin{tabular}{lllllllll}
\hline \hline \multirow{2}{*}{$\mathrm{N}$} & 2.6 & 0 & 10 & 4.6 & 0.3 & 0.2 & $\%$ \\
\cline { 2 - 9 } & 0.53 & 0 & 0.06 & 0.17 & 0.02 & 0.01 & 0.79 & $\mathrm{~kg}$ \\
\hline \multirow{2}{*}{$\mathrm{A}$} & 5 & 10 & 10 & 2.5 & 6 & 1.5 & $\%$ \\
\cline { 2 - 9 } & 1.03 & 1.42 & 0.06 & 0.09 & 0.41 & 0.06 & 3.85 & $\mathrm{~kg}$ \\
\hline \hline
\end{tabular}

\section{0- Chemical Formula of MSW}

To derive the chemical formula of MSW should be revised mass element of solid waste, as moisture in solid waste converts into hydrogen and oxygen due to heat in incinerators. The final revised mass of element content of whole Basrah solid waste can be seen in Table 7. Chemical composition of MSW was consist of 50.39\% of Carbon, $33.78 \%$ of Oxygen, $6.51 \%$ of Hydrogen, $1.55 \%$ of Nitrogen, $0.22 \%$ of Sulfur, and $7.55 \%$ of Ash. Hence, the chemical formula of the solid waste sample with sulfur was $\mathrm{C}_{620} \mathrm{H}_{953} \mathrm{O}_{312} \mathrm{~N}_{16} \mathrm{~S}$ and its chemical formula without sulfur was $\mathrm{C}_{38} \mathrm{H}_{58} \mathrm{O}_{19} \mathrm{~N}$. While the chemical formula of a typical solid waste sample with sulfur is $\mathrm{C}_{650} \mathrm{H}_{990} \mathrm{O}_{417} \mathrm{~N}_{9.5} \mathrm{~S}$ and without sulfur $\mathrm{C}_{68} \mathrm{H}_{104} \mathrm{O}_{44} \mathrm{~N}$.

TABLE VII: Determination of approximate chemical formula with and without sulphur.

\begin{tabular}{llllllll}
\hline \hline \multirow{2}{*}{ Component } & \multirow{2}{*}{ Dry Mass $(\mathrm{kg})$} & \multirow{2}{*}{ Wet Mass $(\mathrm{kg})$} & percent by mass & \multirow{2}{*}{$\mathrm{kg} / \mathrm{mol}$} & $\mathrm{mol}$ & \multicolumn{2}{c}{ mol ratio } \\
\cline { 5 - 8 } & & & & & & sulfur=1 & nitrogen=1 \\
\hline Carbon & 25.69 & 45.96 & 50.39 & 12.01 & 2.139 & 620.01 & 37.86 \\
\hline Hydrogen & $3.32^{*}$ & 5.97 & 6.51 & 1.01 & 3.287 & 952.79 & 58.18 \\
\hline Oxygen & $17.22^{* *}$ & 32.71 & 33.78 & 16 & 1.076 & 311.96 & 19.05 \\
\hline Nitrogen & 0.79 & 1.85 & 1.55 & 14.01 & 0.056 & 16.34 & 1.00 \\
\hline Sulfur & 0.11 & 0.27 & 0.22 & 32.01 & 0.003 & 1.00 & 0.06 \\
\hline Ash & 3.85 & 3.85 & 7.55 & & & & \\
\hline Total & 50.98 & 90.61 & 100.00 & & & & \\
\hline \hline
\end{tabular}

Note : *Hydrogen mass $(\mathrm{H})=3.27+(2 / 18)(90.61-50.98)=3.32$

** Oxygen mass $(\mathrm{O})=16.87+(16 / 18)(90.61-50.98)=17.22$

\section{1- Calorific or Heating Value of MSW}

The modified Dulong's formula (Eq. 3) was used to determine the heating values of MSW with the data obtained from the ultimate analysis [13].

$$
H V\left(\text { in } \frac{k J}{k g}\right)=337 C+1428\left(H-\frac{O}{8}\right)+9
$$

Where $\mathrm{C}=$ Carbon $\%, \mathrm{H}=$ hydrogen $\%, \mathrm{O}=$ oxygen $\%$ and $\mathrm{S}=$ sulfur $\%$ For determining the approximate chemical component using the generated wastage and percentage composition of carbon, hydrogen, oxygen and sulfur is shown in column 4 of Table 8 . So, heating value of MSW was $20250 \mathrm{~kJ} / \mathrm{kg}$

$\mathrm{HV}=337 * 50.39+1428(6.51-33.78 / 8)+9 * 0.22=20250 \mathrm{~kJ} / \mathrm{kg}$

\section{2- Analysis of Electricity Generated}

Various steps are done to calculate electricity as shown below:

Assume energy efficiency $(\eta)=25 \%$

Steam energy available $=25 \%$ of heat value of MSW $(0.25 \times 20250)=5062.49 \mathrm{~kJ} / \mathrm{kg}$

Above calculated steam energy is used to run the turbines, these turbines are coupled with generators which produces electricity. Heat rate is the heat input required to produce one unit of electricity $(\mathrm{kWh})$. Since $1 \mathrm{kWh}=$ $3,600 \mathrm{~kJ} / \mathrm{h}$, then,

Electric power generation $=$ Steam energy $\div 3600=5062.49 \div 3600=1.40625 \mathrm{kWh} / \mathrm{kg}$

Total weight of solid waste collected from Basrah city in $2014=2885.592$ tons/day

Total electric power generation $=1.40625 \times 2885592=4057856 \mathrm{kWh} /$ day

Station service allowance $=6 \%$ of total electric power generation $=0.06 \times 4057856=243471 \mathrm{kWh} / \mathrm{day}$ 
Unaccounted heat loss $=5 \%$ of electric power generation $=0.05 \times 4057856=202893 \mathrm{kWh} / \mathrm{day}$

Net electric power generation $=$ Electric power generation $-($ station service allowance + unaccounted heat loss)

Net electric power generation $=4057856-(243471+202893)=3611492 \mathrm{kWh} / \mathrm{day}=3611.49 \mathrm{MWh} / \mathrm{day}$

The above generated electricity is for one day and one day has 24 hours, so using this net electric power is calculated for per hour basis.

Net electric power generated $=3611.49 \mathrm{MWh} / 24 \mathrm{~h}=150.479 \mathrm{MW} \approx 150 \mathrm{MW}$

Hence, if WTE incineration method is applied on all the 2885.592 tons/day solid waste of Basrah city than total of $3611.49 \mathrm{MWh} /$ day units can be generated which is equal to $150 \mathrm{MW}$. Basrah Governorate electricity demand is $700 \mathrm{MW}$. So, Electricity generated from solid waste can fulfill $21 \%$ of this demand. Besides electricity generation solid waste volume is greatly reduced (up to 90\%) due to conversion of solid waste into ash which solves solid waste management problem.

\section{3- Electrical Output of Plant}

Simulation of electrical output $\left(\mathrm{E}_{\mathrm{i}}\right)$ for the mass-fired combustor power plant with energy input $\left(\mathrm{E}_{\mathrm{o}}\right)$ of $20250 \mathrm{~kJ} / \mathrm{kg}$ from total solid waste generation rate of 2885.592 ton/day for Basrah Governorate in 2014. Simulation can be carried out by assuming different operating efficiencies $(\eta)$ for the mass-fired combustor power plant by Eq. $4[14,15]$

$$
E_{o}=\eta \cdot E_{i}
$$

The potential for electrical energy generation and assumed overall efficiency values that range between $25 \%$ to $80 \%$ can be projected as shown in Fig. 3.

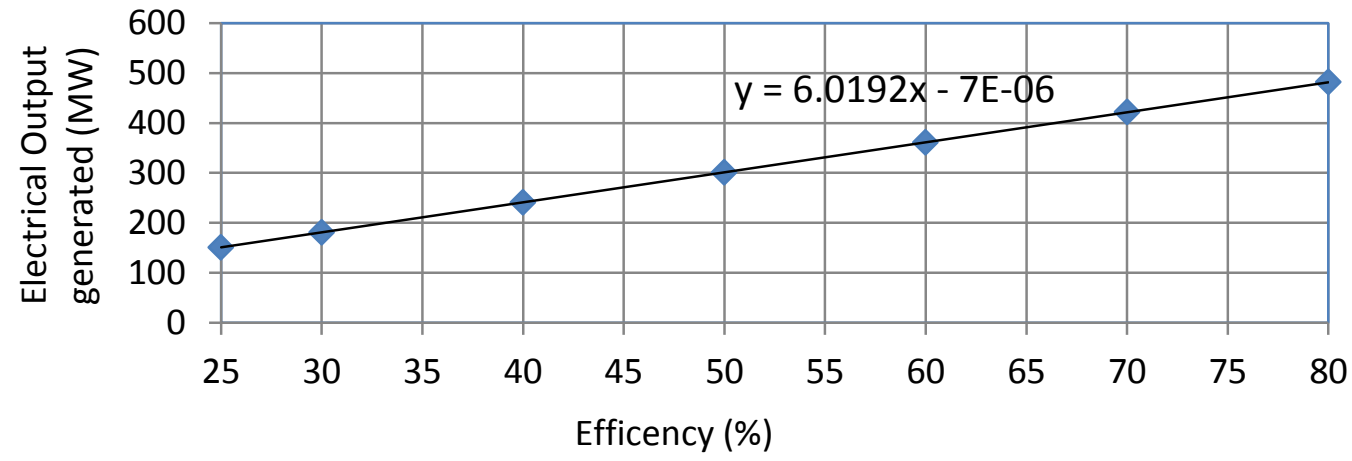

Fig. 3: simulation electrical energy outputs for different efficiencies.

\section{4- Projection of Electricity Power generated from MSW}

projection of electricity potential power generated from MSW has been produced representing electrical power generation that could be contributed to the grid for Basrah Governorate out to year 2036. This projection was done under the following assumptions:-

- Annual Population Growth rate was a constant as $2.7 \%$ [11]

- Average MSW generation rate was a constant as $1.05 \mathrm{~kg} / \mathrm{capita} / \mathrm{day}$ [11]

- No change in composition of MSW

- Overall efficiency $(\eta)$ of MSW incineration plant to generate electricity was a constant as $25 \%$

- Electrical daily demand of Basrah Governorate was a constant as $700 \mathrm{MW}$

- Generating Electricity Contribution to the Grid $($ GECG $)=($ Electrical Generated/ Demand $) \times 100$ 
The projection results of electrical generation has been depicted in Fig. 4. As evidence from Fig. 4, It is projected that the electric power generation could reach a maximum capacity of $270 \mathrm{MW}$ in 2036 with electrical fulfill to the demand of $39 \%$.

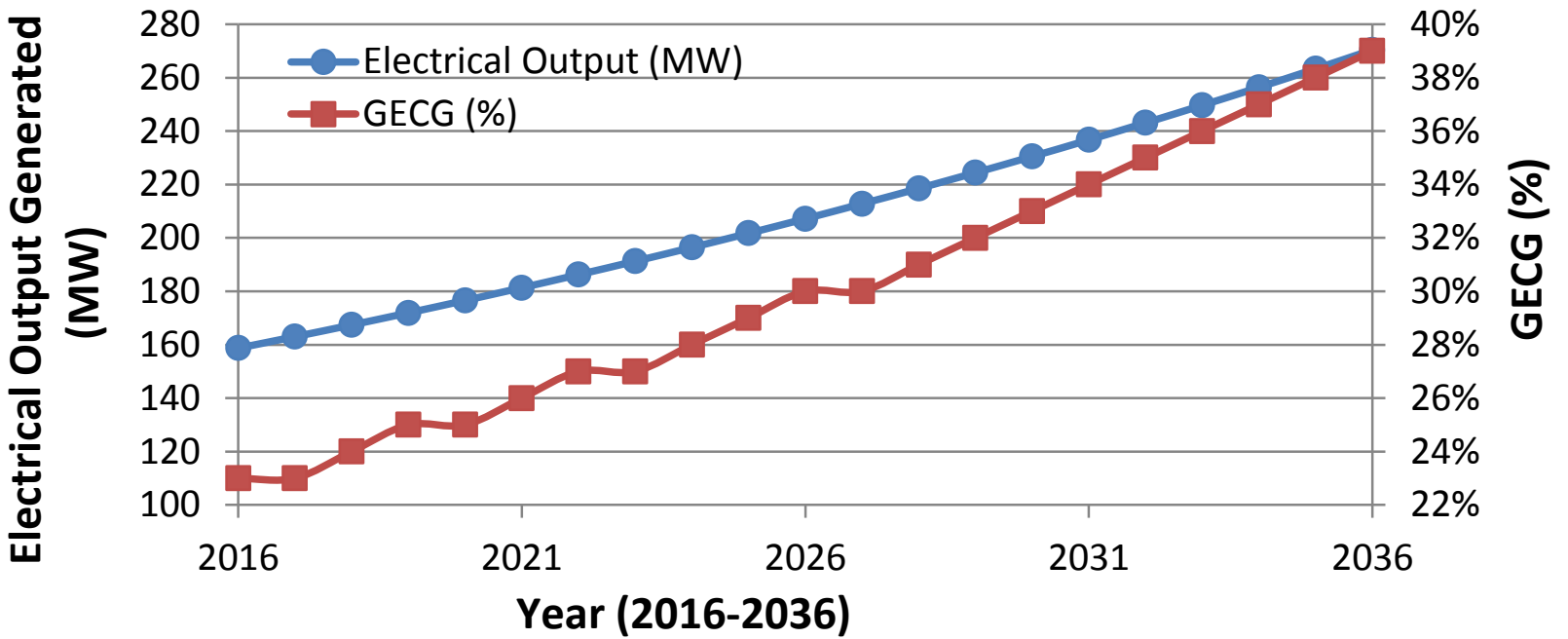

Fig 4: Projections of MSW and Electricity Generation of Basrah Governorate over the next 20 years (2016-2036)

\section{5- Cost-Benefit Analysis (CBA).}

The tool to be used to assess the economics of a WTE incineration plant for Basrah Governorate is a CostBenefit Analysis (CBA). CBA is a standard method of comparing the social cost and benefits of alternative investments projects. Costs and benefits are measured and then weighed up against each other in order to generate criteria for decision-making. Typically one of many decision criteria are used the Net Present Value (NPV). A project is deemed to be acceptable if the NPV is positive. Net present value (NPV) for a discount rate ( $r)$ and number of years $(t=n)$ is calculated based on following formula;

$$
N P V=\sum_{t=1}^{n} \frac{(\text { Benfit }- \text { Cost })_{t}}{(1+r)^{t}}
$$

Discount rate of 5\% was used in this research and 20 years cash flow forecast was used. Calculations of Cost-Benefit Analysis (CBA) of the project has been shown in Table 8. These analysis has been done under the following assumption:

- The proposed waste incineration project consist of four plants with a total capacity 5000 ton/day (1250 ton/day each one). These plants distributed in different locations in north, middle, south and east of Basrah Governorate.

- The life of project take as 20 years (2016-2036)

- The capital cost on WTE incineration plant was considered as $200 \mathrm{USD} /$ ton of annual waste. The capital cost was 365,000,000 USD, which has been calculated for the biggest annual waste in year 2036 [16].

- Cost of Operation and Maintenance (O\&M) was considered as 15\% of capital cost, i.e, 30 USD/tone of waste [17].

- Benefit of electricity sale: the price of electricity was considered as 0.04 USD/kWh [18,19].

- Benefit from Saved cost on landfilling: the capital cost and operation of landfill was considered as 23 USD/ton [20]. The saved cost of landfilling has been considered to become 17.25 USD/ton due to the Incineration will be reduces the waste volume by $90 \%$ and weight by $75 \%$.

As result of CBA The net present value (NPV) was estimated at +653 million USD. The financial analysis shows positive net present value (For project net benefits). The positive value of NPV means that project will be Profitable and successful project. Therefore project is acceptable in the point of net present value and should be undertaken .

TABLE VIII: Cost - Benefit calculations of the waste incineration Project for 20 years (2016-2036) 


\begin{tabular}{cccccccc}
\hline \hline Year & $\begin{array}{c}\text { MSW } \\
\text { (kg/day) }\end{array}$ & $\begin{array}{c}\text { Power } \\
\text { (MW) }\end{array}$ & $\begin{array}{c}\text { Operation } \\
\text { (USD) }\end{array}$ & $\begin{array}{c}\text { Landfill } \\
\text { (USD) }\end{array}$ & $\begin{array}{c}\text { Electricity } \\
\text { (USD) }\end{array}$ & $\begin{array}{c}\text { Cost } \\
\text { (USD) }\end{array}$ & $\begin{array}{c}\text { Benefit } \\
\text { (USD) }\end{array}$ \\
\hline 2016 & $3,043,518$ & 158.7 & $33,326,522$ & $14,372,063$ & $55,613,524$ & $398,326,522$ & $69,985,587$ \\
\hline 2017 & $3,125,693$ & 163.0 & $34,226,338$ & $14,760,108$ & $57,115,089$ & $34,226,338$ & $71,875,198$ \\
\hline 2018 & $3,210,087$ & 167.4 & $35,150,453$ & $15,158,633$ & $58,657,202$ & $35,150,453$ & $73,815,835$ \\
\hline 2019 & $3,296,759$ & 171.9 & $36,099,511$ & $15,567,914$ & $60,240,940$ & $36,099,511$ & $75,808,854$ \\
\hline 2020 & $3,385,771$ & 176.6 & $37,074,192$ & $15,988,245$ & $61,867,436$ & $37,074,192$ & $77,855,682$ \\
\hline 2021 & $3,477,187$ & 181.3 & $38,075,198$ & $16,419,929$ & $63,537,861$ & $38,075,198$ & $79,957,790$ \\
\hline 2022 & $3,571,071$ & 186.2 & $39,103,227$ & $16,863,267$ & $65,253,382$ & $39,103,227$ & $82,116,649$ \\
\hline 2023 & $3,667,490$ & 191.3 & $40,159,016$ & $17,318,575$ & $67,015,225$ & $40,159,016$ & $84,333,800$ \\
\hline 2024 & $3,766,512$ & 196.4 & $41,243,306$ & $17,786,176$ & $68,824,632$ & $41,243,306$ & $86,610,807$ \\
\hline 2025 & $3,868,208$ & 201.7 & $42,356,878$ & $18,266,403$ & $70,682,900$ & $42,356,878$ & $88,949,303$ \\
\hline 2026 & $3,972,650$ & 207.2 & $43,500,518$ & $18,759,598$ & $72,591,345$ & $43,500,518$ & $91,350,943$ \\
\hline 2027 & $4,079,911$ & 212.8 & $44,675,025$ & $19,266,105$ & $74,551,301$ & $44,675,025$ & $93,817,406$ \\
\hline 2028 & $4,190,069$ & 218.5 & $45,881,256$ & $19,786,291$ & $76,564,194$ & $45,881,256$ & $96,350,485$ \\
\hline 2029 & $4,303,201$ & 224.4 & $47,120,051$ & $20,320,522$ & $78,631,430$ & $47,120,051$ & $98,951,952$ \\
\hline 2030 & $4,419,387$ & 230.5 & $48,392,288$ & $20,869,174$ & $80,754,471$ & $48,392,288$ & $101,623,645$ \\
\hline 2031 & $4,538,711$ & 236.7 & $49,698,885$ & $21,432,644$ & $82,934,851$ & $49,698,885$ & $104,367,496$ \\
\hline 2032 & $4,661,256$ & 243.1 & $51,040,753$ & $22,011,325$ & $85,174,089$ & $51,040,753$ & $107,185,413$ \\
\hline 2033 & $4,787,110$ & 249.6 & $52,418,855$ & $22,605,631$ & $87,473,791$ & $52,418,855$ & $110,079,422$ \\
\hline 2034 & $4,916,362$ & 256.4 & $53,834,164$ & $23,215,983$ & $89,835,584$ & $53,834,164$ & $113,051,567$ \\
\hline 2035 & $5,049,104$ & 263.3 & $55,287,689$ & $23,842,816$ & $92,261,148$ & $55,287,689$ & $116,103,964$ \\
\hline 2036 & $5,185,429$ & 270.4 & $56,780,448$ & $24,486,568$ & $94,752,185$ & $56,780,448$ & $119,238,753$ \\
\hline & Capital Cost $=365$ million USD & & & NPV=+653 million USD \\
\hline \hline
\end{tabular}

The variation of cost and benefit along the project life has been depicted in Fig. 5. This figure shows that the initial investment cost is very high, while from the year of operation on annual benefits become more than costs and the together rise steadily because of the increase in waste volume. The variation of present value along the project life has been depicted in Fig. 5.it evident that, the present value was positive at all years of project life except the first years due to the high capital cost. The variation of NPV with discount rate was shown in Fig. 6. The will be profitable until discount rate reach to $12 \%$.

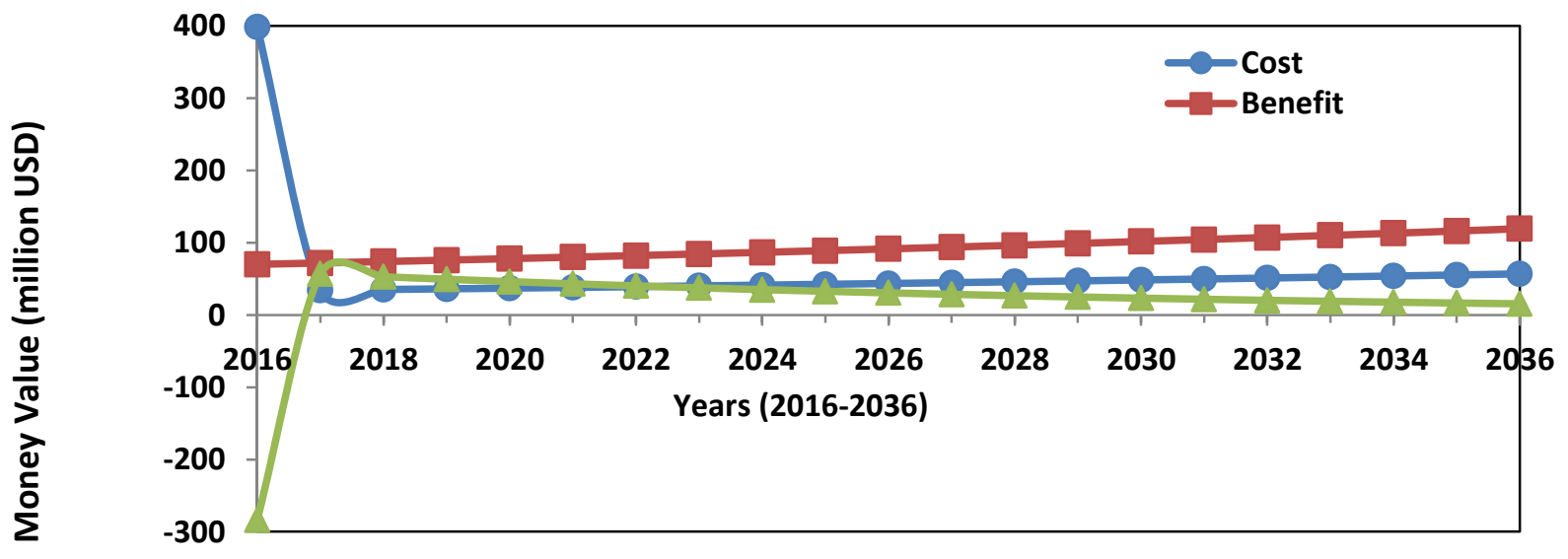

Fig. 5: Cost, Benefit and Net present value variation during of the WTE project life (2016-2036) 


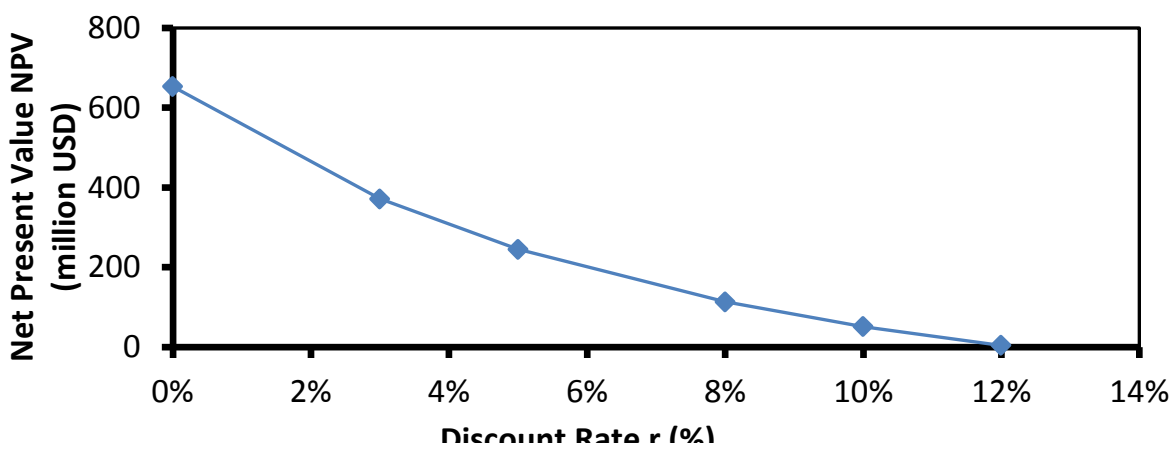

Fig. 6: Net Present value of WTE project variation with discount rate

\section{6- Conclusions}

Based on the results and within the limitations of this study the following conclusions can be drawn for Basrah Governorate:

- Food waste was the most common component in Basrah Governorate, which was approximately $60.5 \%$ of the total MSW. Other fractions were $14.5 \%, 7.2 \%, 5 \%, 4.1 \%, 2.8 \%, 2.7 \%$, and $0.6 \%$ of plastic, paper, wood, textile, glass, metal, and Rubber.

- Compostable (organic or food waste) make up on average $60.5 \%$ of the total MSW stream, while recyclables (plastics, metal, glass, wood, textile) make up 37\% of the total MSW stream

- The density of MSW was ranged from $194.5 \mathrm{~kg} / \mathrm{m} 3$ to $218.2 \mathrm{~kg} / \mathrm{m} 3$ with an average density of $206.7 \mathrm{~kg} / \mathrm{m} 3$

- The moisture of MSW was ranged from $39.0 \%$ to $45.7 \%$ with an average moisture of $42.3 \%$.

- For years 2011 - 2014, the average generation rates of municipal solid waste were ranged from 1.05 to 1.97 $\mathrm{kg} / \mathrm{capita} /$ day with an average generation rate of $1.4 \mathrm{~kg} / \mathrm{capita} /$ day

- Chemical composition of MSW was consist of 50.39\% of Carbon, 33.78\% of Oxygen, $6.51 \%$ of Hydrogen, $1.55 \%$ of Nitrogen, $0.22 \%$ of Sulfur, and $7.55 \%$ of Ash.

- The chemical formula of the solid waste sample with sulfur was $\mathrm{C}_{620} \mathrm{H}_{953} \mathrm{O}_{312} \mathrm{~N}_{16} \mathrm{~S}$ and its chemical formula without sulfur was $\mathrm{C}_{38} \mathrm{H}_{58} \mathrm{O}_{19} \mathrm{~N}$.

- Heating value of MSW was $20250 \mathrm{~kJ} / \mathrm{kg}$

- Net electric power generated from MSW was approximately $150 \mathrm{MW}$ at year 2014 that can contributed by $21 \%$ of this demand for Basrah Governorate.

- It is projected that the electric power generation could reach a maximum capacity of $270 \mathrm{MW}$ in 2036 with electrical fulfill to the demand of $39 \%$.

- The proposed waste incineration project consist of four plants with a total capacity 5000 ton/day (1250 ton/day each one). These plants to be construct in four locations (north, middle, south and east) of Basrah Governorate. The life of project take as 20 years (2016-2036). Capital cost of was expected around $365,000,000$ USD. As result of CBA, the net present value (NPV) was estimated at +653 million USD with discount rate $5 \%$. Therefore project is acceptable in the point of net present value and should be undertaken until discount rate $12 \%$.

\section{7- References}

[1] J.N Fobil \& D.Carboo, "Evaluation of municipal solid wastes (MSW) for utilisation in energy production in developing countries", Int. J. Environmental Technology and Management, vol. 5, pp. 76-87, Jan. 2005.

[2] R. Kothari, V.V. Tyagi, \& A. Pathak, "Waste-to energy: A way from renewable energy sources to sustainable development", Renewable and Sustainable Energy Reviews, vol. 14, pp. 3164-3170, Dec. 2010. https://doi.org/10.1016/j.rser.2010.05.005

[3] A Rabl, JV Spadaro, A Zoughaib, "Environmental impacts and costs of solid waste: a comparison of landfill and incineration", Waste Management \& Research, vol. 26 no. 2, pp. 147-62, Apr 2008

https://doi.org/10.1177/0734242X07080755 